\title{
CLASSROOM COMMUNICATION SKILLS: THE NEED TO FILL A GAP IN THE TRAINING OF TEACHERS OF SPANISH AS A FOREIGN LANGUAGE
}

\author{
Francisco J. Rodríguez Muñoz \\ Área de Didáctica de la Lengua y la Literatura, Departamento de Educación, Universidad de \\ Almería, Almería, España \\ frodriguez@ual.es \\ Víctor M. Madrid Navarro \\ Círculo Andaluz de Lingüistica Aplicada (CALA), Universidad de Almería, Almería, España \\ vicmad84@gmail.com
}

\begin{abstract}
This paper sets out the necessity of examining the communication skills of teachers of Spanish as a foreign language as conducted in other socio-educative contexts. According to this objective, the paper begins with a review of theoretical efforts that have been made during recent years referring to research methodology (such as instruments), and to their main results. This leads to a discussion of the training needs that teachers of Spanish as a foreign language presently face for the development of their communication skills in the classroom and, in general terms, the paper discusses the different types of ideas and strategies that must be considered during teachers' instruction. Finally, this brief proposal expects to be the seed of future research projects that impact positively on the improvement of teachers' communication competence, whereby the ideas discussed here are taken as a nuclear component in the frame of future teaching competence.
\end{abstract}

Keywords: professional skills; teacher training; teaching competence; instructional communication competence; assessment of communication skills; teaching Spanish as a foreign language; discursive strategy; discursive practice; interactive strategy; interactional competence.

\section{Introduction}

Teaching competence is made up of abilities, knowledge and attitudes that teachers need to teach appropriately in all occupational situations. The content of this competence has evolved to introduce new skills expected to benefit the teaching-learning process in all aspects (see Cazden, 1986, 1988; Cazden, John-Steiner \& Hymes, 1972; Edwards, 1993; Fisher, 1993; Lemke, 1990; Mercer, 1995; Seedhouse, 2005, 2008; Tsui, 2001; Walsh, 2006; Worley, Titsworth, Worley \& Cornett-DeVito, 2007). Qualities such as motivating students to participate, and to be self-sufficient and responsible for their own learning, working on situations of meaningful learning, or the correct use and exploitation of technologies are some of the new abilities that teachers must present in the $21^{\text {st }}$ century. According to Cornett-DeVito and Worley (2005), instructional communication competence refers to "the teacher instructor's motivation, knowledge and skill to select, enact and evaluate effective and appropriate, verbal and nonverbal, interpersonal and instructional messages filtered by student-learners' perceptions, resulting in cognitive, affective and behavioral studentlearner development and reciprocal feedback" (p. 315).

In this context, the current paper highlights the relevance of a number of skills that must be kept in mind when describing and specifying the elements that determine the teaching professional's success in their teaching daily activities: skills that are together known as communication skills. Thus, the main goal of this proposal will be to insist on the need of assigning such competence to teachers of Spanish as a foreign language (SFL) from other research projects that have been based on the same issue in other academic fields (in particular, in the training that future teachers receive). Specifically, attempts will be made to know the procedures of assessment that have been applied to understand the teachers' communication skills awareness, reviewing several studies on educational communication and arguing their results.

In concordance with the above-mentioned purposes, the content is divided into three sections: first, teachers' communication skills are explained in the frame of teaching competence; second, the need for a communicative training for SFL teachers is demanded; and third, the main conclusions are listed.

\section{Teachers' communication skills in the frame of teaching competence}

An important component within any teaching profile, in addition to possessing the specialised knowledge concerning a specific subject, consists of knowing how to transmit it to students - in the words of Austin (1962) and Lomas (2001): "how (to teach) to do things with words". For that, it is necessary to create a good environment of work in which the communicative situations or events that take place are efficiently solved for teachers and learners - the two basic participants who are placed on both edges of the communication process within the educational context. Consequently, teachers' communication skills turn 
into a key element for the correct running of all the elements that appear and combine during the teachinglearning process, which constitutes an interactive process of talk and communication at the same time.

In the last few years, different research studies have been accomplished with the goal of analysing the level of acquisition of communication skills by future teachers during their university education. Such studies have often used questionnaires as instruments directed at analysing teachers' communicative training perceptions. A precedent in this context is the research group 'Research on educational communication' (HUM871) led by Gallego Ortega at the University of Granada. In the frame of this research team, Domingo Segovia, Gallego Ortega, García Aróstegui and Rodríguez Fuentes (2010) focus on future teachers' communication skills. In particular, the aforementioned research was based on two questionnaires: one, related to Education students' self-assessment, which was completed by eight-hundred and ninety students divided into first and last grade; and another, destined for university professors. They were also used to reflect on how communication skills are considered in the syllabus of students' subjects.

According to the aim of knowing the procedures to assess professors' communication skills, Domingo Segovia et al. (2010) divided their research questionnaire into sixty items broken down into five blocks: (1) competence as a good speaker; (2) competence as a good addressee; (3) competence and communication skills in class; (4) communication competence to serve in meetings; and (5) communication competence to practise the tutoring. The items are organised in a Likert scale of five points (invalid, inadequate, adequate, high, and very high command). As the results revealed, the first grade students estimated their communication skills were inadequate in every aspect, with the exception of competence as a good recipient, which was valued as adequate. In relation to the third grade students, a light, although limited, improvement was noticed in their self-assessment during their instruction, expressing a scoring on average of adequate in every single contents block.

Concerning the syllabus analysis, the research showed that communication skills have a limited presence. This competence is only included in four subjects: General Didactics; Educational and Developmental Psychology in School Age Children; Teaching and Development of Linguistic Skills; and Rhythmic and Dance Training, with a highly superficial consideration in some of them. These data suggest that future teachers do not learn enough communication skills during their training years at university and that their level of communicative competence is low; even so, students' perceptions of their communication skills improves over the academic years.

One-hundred and fifty-two university professors participated in the research of Domingo Segovia, Gallego Ortega and Rodriguez Fuentes (2013), reflecting on the topic of communicative abilities in the questionnaire. This questionnaire was divided into the following blocks: (1) competence as a good speaker in interpersonal communication; (2) competence as a good addressee of the communication process; (3) competence and communication skills in the classroom; (4) communication competence to proceed in meetings with parents or colleagues; and (5) communication competence's consideration in the tutor role. Using the questionnaire, professors assessed whether communication skills were employed during their lessons, the way students acquired such abilities and whether these competences should be more developed in the new curriculum of their university.

Results showed a discouraging forecast. With regard to whether communication skills were employed in the classroom, and in a general way in every content block represented in the questionnaire, less than 30 per cent of the informants affirmed this, while the remaining 70 per cent declared they employed it in an inadequate way or were unable to say whether they employed it or not in classroom. Regarding their perception about the students' communication skills acquisition, only 26 per cent of the professors thought that students acquire communication skills in an adequate way as recipients, and only five per cent considered they acquire the necessary communication skills to conduct themselves in meetings. Once again, more than the 70 per cent of the informants believed that students do not acquire such skills or they could not say either they acquire them or not. Beyond this, 69 per cent of the professors thought that they should take into account these competences in the development of future teaching plans.

In relation to the Education students' self-perceptions, the research of Gallego Ortega and Rodríguez Fuentes (2015) is based on a questionnaire in which second and fourth grade Education students participated, in particular students from Special Education at the University of Granada (Spain). For this research, the same questionnaire that was used by Domingo Segovia et al. (2010) and Domingo Segovia, Gallego Ortega and Rodríguez Fuentes (2013) was used. On the one hand, results show an inadequate self-assessment for the second grade students in all the communication skills, except for the competences as a good addressee, which reveal an adequate level. On the other hand, fourth grade students consider their level is adequate in the different communication skills. In this way, a slight increase in the assessment can be noticed when 
perceiving the progress of the communicative competence during training, but not enough significance to reach a high level of acquisition.

Finally, the instrument developed by Castellá, Comellas, Cros and Vilà (2007) summarises the assessment of communication skills according to two interactive strategies: discursive strategies of social relationships in the classroom, and discursive strategies of knowledge building. All these backgrounds have to be present with a view to analysing the communication abilities and needs of future SFL teachers.

\section{The communicative training needs of teachers of Spanish as a foreign language}

The existence of communication skills in the teacher figure is very necessary to know how to manage different communicative situations suitably that arise in the classroom. This need is revealed in a deeper way in the context of SFL teachers. These teachers have to provide their students with all the resources to be communicatively competent and turn into a model of the competent user as well. For this purpose, an improvement in the teaching of communication skills used in the SFL classroom is required with the intention of achieving an effective communication during the teaching-learning process. As Cepik (2014) points out, a good foreign language teacher must be positive and motivating, with the ability to recognise learners' concerns and offer support for their resolution.

The concept of interactive strategy, whose control must be effective for SFL teachers in classroom, has been often associated with communication skills. Following Young (2011), the term interactional competence (IC) "has been used by different scholars with different shades of meaning in several different areas of second language learning, teaching, and testing" (p. 426). This author explains that IC can be observed (or its absence noted) in spoken interaction and in a discursive practice. Thus, on the one hand, "although writing has not been considered as contributing substantially to IC, nonverbal semiotic resources such as gesture, gaze, posture, kinesics, and proxemics are frequently considered, as indeed are verbal prosody, rhythm, and intonation" (p. 427). On the other hand, discursive practices are defined as "recurring episodes of social interaction in context, episodes that are of social and cultural significance to a community of speakers" (p. 427).

Tough (1977) identifies five types of dialogue strategies that can be used in interaction with the student:

1. Orienting strategies: questions and open comments that invite the students to choose how to respond to a particular topic and context.

2. Enabling strategies: these motivate students to provide further information, fuller interpretations or to reconsider a statement.

3. Informing strategies: teachers must be prepared to offer students complementary data and ideas.

4. Sustaining strategies: oriented towards assuring the student of the teacher's attention.

5. Concluding strategies: these indicate an intention to conclude the dialogue or to bring a specific topic to a close before reorienting the discourse.

Previously, Flanders (1970) develops an observational tool in order to classify the verbal behaviour of teachers and students as they interact in the classroom. For that, he proposes a system formed by ten different categories, as shown in Table 1

Flanders' interaction analysis category system

Table 1

\begin{tabular}{|c|c|c|l|}
\hline \multicolumn{2}{|l|}{} & $\begin{array}{l}\text { Category } \\
\text { number }\end{array}$ & \multicolumn{1}{|c|}{ Activity } \\
\hline \multirow{2}{*}{ Teacher talk } & 1 & $\begin{array}{l}\text { Accept feeling: accepts and clarifies an attitude or the } \\
\text { feeling tone of a student in a non-threatening manner. } \\
\text { Feeling may be positive or negative. }\end{array}$ \\
\cline { 3 - 4 } & Response & 2 & $\begin{array}{l}\text { Praises } \text { or encourages: praises or encourages student } \\
\text { action or behaviour. Jokes that release tension, but not } \\
\text { at the expense of another individual. Nodding head, or } \\
\text { saying 'umhm?' }\end{array}$ \\
\cline { 3 - 4 } & 3 & $\begin{array}{l}\text { Accepts } \text { or uses ideas of students: clarifying or building } \\
\text { or developing ideas suggested by a student. Teacher } \\
\text { extensions of student ideas are included but as the } \\
\text { teacher brings more of his own ideas into play, shift to } \\
\text { category five. }\end{array}$ \\
\cline { 3 - 4 } & 4 & $\begin{array}{l}\text { Ask questions: asking a question about content or } \\
\text { procedure with the intent that a student may answer. }\end{array}$ \\
\hline
\end{tabular}

(continued) 
Table 1 (continued)

Flanders' interaction analysis category system

\begin{tabular}{|c|c|c|c|}
\hline & & $\begin{array}{l}\text { Category } \\
\text { number }\end{array}$ & Activity \\
\hline \multirow{3}{*}{ Teacher talk } & \multirow{3}{*}{ Initiation } & 5 & $\begin{array}{l}\text { Lecturing: giving facts or opinions about content or } \\
\text { procedures; expressing his own ideas; asking rhetorical } \\
\text { questions. }\end{array}$ \\
\hline & & 6 & $\begin{array}{l}\text { Giving direction: directions, commands or orders to } \\
\text { which a student is expected to comply. }\end{array}$ \\
\hline & & 7 & $\begin{array}{l}\text { Criticizing or justifying authority: statements intended } \\
\text { to change student behaviour from non-acceptable to } \\
\text { acceptable pattern; stating why the teacher is doing } \\
\text { what he is doing }\end{array}$ \\
\hline \multirow[b]{2}{*}{ Student talk } & Response & 8 & $\begin{array}{l}\text { Student talk in response to teacher: talk by students in } \\
\text { response to teacher. Teacher initiates the contact or } \\
\text { solicits student statement. }\end{array}$ \\
\hline & Initiation & 9 & $\begin{array}{l}\text { Student talk initiated by the student: talk by students } \\
\text { which they initiate. It 'calling on' student is only to } \\
\text { indicate who may talk next, observer must decide } \\
\text { whether student wanted to talk. It he did, use this } \\
\text { category. }\end{array}$ \\
\hline Silence & & 10 & $\begin{array}{l}\text { Silence or confusion: pauses, short periods of confusion } \\
\text { in which communication cannot be understood by the } \\
\text { observer. }\end{array}$ \\
\hline
\end{tabular}

Due to the foreign language students having to be the principal actors of the teaching-learning process and taking into account their specific features and needs, SFL teachers must adapt to these and update their professional competences. Cepik (2014) sums up these competences in a triad: a) linguistic (or communicative) skills, b) cultural knowledge (or intercultural competences), and c) academic achievement.

Education must not be only based on grammatical, lexical or orthographic knowledge (that is, on the linguistic competence or grammatical Chomskyan model), but it must also search for the way to transform learners into competent users - including the cultural knowledge and socio-pragmatic skills - of communication.

\section{Conclusions}

Research studies reviewed in this paper begin to demonstrate the importance of communication skills in the frame of the teaching-learning process, as well as the lack of this kind of study when analysing SFL teachers' needs. Proposals like those that are gathered in this paper are necessary to go deeper in a more determined way into the existing issue and, above all, to provide coherent solutions to improve the communication process in classroom.

As a future line of research, study about communicative instruction and the appropriate use of this teaching competence must be expanded as soon as possible to the specific field of teaching SFL to be able to analyse the level of command that future teachers of Spanish possess and to find solutions that improve the teaching-learning process.

\section{Acknowledgements}

This publication has been carried out within the innovation group Educación Comunicativa [Educational Communication] (Educom), coordinated by Dr. Francisco J. Rodríguez Muñoz, thanks to the support of the Vice-rectorate of Official Teaching and Continuous Training of the University of Almería.

\section{References:}

Austin, J. (1962). How to do things with words. Oxford: Clarendon Press.

Castellà, J. M., Comellas, S., Cros, A., \& Vilà, M. (2007). Entendre('s) a classe. Les estratègies comunicatives dels docents ben valorats. [Be understood in class. The communicative strategies of well-valued teachers]. Barcelona: Graó.

Cazden, C. B. (1986). Classroom discourse. In M. E. Wittrock (Ed.), Handbook of research on teaching (pp. 432-463). Nueva York: Macmillan.

Cazden, C. B. (1988). Classroom discourse. The language of teaching and learning. Portsmouth, NH: Heinemann Educational Books. 
Cazden, C. B., John-Steiner, V. P., \& Hymes, D. (1972). Functions of language in the classroom. London/New York: Teachers College Press/Columbia University.

Cepik, S. (2014, November-December). Become a "good" foreign language teacher: knowledge, skills and dispositions. The Fountain, 102. Retrieved from http://www.fountainmagazine.com/Issue/detail/becoming-a-good-november-2014

Cornett-DeVito, M., \& Worley, D. W. (2005). A front row seat: A phenomenological investigation of students with learning disabilities. Communication Education, 54(4), 312-333. http://dx.doi.org/10.1080/03634520500442178

Domingo Segovia, J., Gallego Ortega, J. L., \& Rodríguez Fuentes, A. (2013). Percepción del profesorado sobre la competencia comunicativa en estudiantes de Magisterio. [Perception of professors on the communicative competence of students of Education]. Perfiles Educativos, 35(142), 54-74. http://dx.doi.org/10.1016/S0185-2698(13)71849-X

Domingo Segovia, J., Gallego Ortega, J. L., García Aróstegui, I., \& Rodríguez Fuentes, A. (2010). Competencias comunicativas de maestros en formación. [Communicative competences of teachers in pre-service education]. Profesorado: Revista de Currículum y Formación del Profesorado, 14(2), 303-323.

Edwards, D. (1993). Concepts, memory, and the organization of pedagogic discourse: A case study. International Journal of Educational Research, 19(3), 205-225.

Fisher, E. (1993). Distinctive features of pupil-pupil classroom talk and their relationship to learning: How discursive exploration might be encouraged. Language and Education, 7(4), 239-257. https://doi.org/10.1080/09500789309541363

Flanders, N. A. (1970). Analyzing teaching behavior. Reading, MA: Addison-Wesley.

Gallego Ortega, J. L., \& Rodríguez Fuentes, A. (2015). Competencias comunicativas de maestros en formación de educación especial. [The communication skills of teachers in special education training]. Educación y Educadores, 18(2), 209-225. http://dx.doi.org/10.5294/edu.2015.18.2.2

Lemke, J. L. (1990). Talking science: Language, learning and values. Norwood, NJ: Ablex.

Lomas, C. (2001). Cómo enseñar a hacer cosas con palabras. Teoría y práctica de la educación lingüistica. [How to teach to do things with words. Theory and practice of language education]. 2nd edition. Barcelona: Paidós.

Mercer, N. (1995). The guided construction of knowledge: Talk among teachers and learners. Clevedon: Multilingual Matters.

Seedhouse, P. (2005). Conversation analysis and language learning. Language Teaching, 38(4), 165-187. http://dx.doi.org/10.1017/S0261444805003010

Seedhouse, P. (2008). Learning to talk the talk: Conversation analysis as a tool for induction of trainee teachers. In S. Garton \& K. Richards (Eds.), Professional encounters in TESOL. Discourses of teachers in teaching (pp. 42-57). Basingstoke: Palgrave Macmillan. https://doi.org/10.1057/9780230594173_3

Tough, J. (1977). Talking and learning. A guide to fostering communication skills in nursery and infant schools. London: Ward Lock.

Tsui, A. B. M. (2001). Classroom interaction research. In R. Carter \& D. Nunan (Eds.), The Cambridge guide to teaching English to speakers of other languages (pp. 120-125). Cambridge: Cambridge University Press. https://doi.org/10.1017/cbo9780511667206.018

Walsh, S. (2006). Investigating classroom discourse. Abingdon: Routledge. https://doi.org/10.4324/9780203015711

Worley D., Titsworth, S., Worley, D. W., \& Cornett-DeVito, M. (2007). Instructional communication competence: Lessons learned from award-winning teachers. Communication Studies, 58(2), 207-222. http://dx.doi.org/10.1080/10510970701341170

Young, R. F. (2011). Interactional competence in language learning, teaching, and testing. In E. Hinkel (Ed.), Handbook of research in second language teaching and learning (Vol. 2, pp. 426-443). London/New York: Routledge. https://doi.org/10.4324/9780203836507.ch26 